\title{
Acquisition of library materials as a correlation to library services in tertiary institutions.
}

\author{
Dr Rafiu Jimoh Ango. ${ }^{(a)}$ Adeyemo Yusuf Temitope ${ }^{(b)}$ \\ Jrafiu91@gmail.com ${ }^{(a)} \quad$ Yusufmorph700@yahoo.com ${ }^{(b)}$ \\ (a) Department of Library and Information Science ,School Of Information and Communication Studies. Federal Polytechnic Offa Kwara \\ State of Nigeria. 08076670531 \\ (b) ( IT Consultant) 08058581128
}

\begin{abstract}
This study was carried out to evaluate the existing acquisitions, management practices and investigate the opinion of the researcher on the efficiency and effectiveness of the library system in tertiary institutions, Research survey method was employed for the study, the instrument used for data gathering were questionnaire and observation methods. The data was analyse by using frequencies and percentages method. The finding deduced that at the initial stage there was a written policy for the library but at the time this research was conducted it was no longer in use. Weeding of the library materials were performed regularly, while the weeded materials were donated and some kept at the basement. The library was not adequately staffed and funded by the library management, vast majority of the users were not satisfied with available materials. The research, therefore, concluded that there is no adequate provision of funds to the library for the acquisition of library materials and application information technology in cataloging and classification of the library materials was not provided. In addition, the following recommendations were made, based on the findings emphasis should be placed on the orderly arrangement of the library materials to facilitate easy location on the shelf. The selection and acquisition of library materials should be decentralize; more professional staff should be employed to handle the collection development process of the library.
\end{abstract}

Keywords : Acquisitions, Coronations, Library, Information and Science, Cataloging and Classifications, Weeding, Research, Institutions.

\section{Introduction.}

Acquisition development is a fundamental process in establishing and maintaining any library and information system. All the services in the system depend solely on the collection and acquisition without which no effective services can be rendered. acquisition development ( acquisition of materials and it management) involves the overlapping processes of identification, selection, acquisition and evaluation of a collection of library resources e.g. print materials, and visual materials electronic resources for a community of users.

Libraries are strive to develop acquired resources and services to meet the cultural, informational, educational and recreational demands of its target users, because libraries primarily objective is to satisfy the multiple needs of its target users .Osburn (1990), as cited by Umesha, M. B. and Sarasvathy,P. (2017), opined that the basic principles related to collection management such as value and demand, conservator and innovator. The study revealed that selections were a vital for collection development in modern libraries. The scholar pointed out those scientific criteria for selection was indeed pivotal to collection development policies. The scholar suggested that the plans of action such as budget justification and allocation should be designed on the basis of systematic assessment of the needs of users. 
Acquisition is the process of securing materials for the library's collection; this may be through purchase, gifts, exchange, \& legal deposit.The process of acquisition is a fundamental function undertaken in every kind and size of library. The acquisition department is set aside for this purpose and is exclusively responsible for acquisition work, which includes books selection, book ordering and maintenance of materials for effective services rendered in the library.

Acquisition of materials in the academic library will be determined the kind of services rendered to their users. According to the Arizona State library (2011), opined that, these goals include acquiring materials as quickly and economically as possible and minimizing the amount of paperwork, filling and follow up needed. Effective working relationships with vendors are very important as well. he nitty-gritty of an effective acquisition include collection orders, searching and verifying bibliographic information, choosing an option for placing orders, assigning a purchase order, placing an order, bookkeeping, receiving materials, returning books/materials if necessary, processing the books and making payments. Some of these acquisition processes might not apply to all information materials. The slow rate of book production in the country has also created a problem in acquiring quality materials for the library.

\section{The Statement of the Problem.}

The problems that are associated with the procurement of materials in the library is solely dependent on process of collection, acquisition that cannot be underscore in library activities, because of its importance in library services delivery, collection development happened to be one of the area in librarianship that continually affect the quality of services rendered. However, the user's frustrations are a measure of collection development, hence, the necessity for this study.

\section{Objective of the Study.}

This study is aimed to achieve the stated objective.

1. To find out the effect of acquired materials.

\section{Research Question.}

1. What are the material acquired for library services.?

(1a) accessibility.

(1b) determinations of uses.

(1c) rate of usage of library.

(1d) type of information material consulted.

(1e) relevance of shelve books in course of studies.

(1f) users and library (satisfactions). 


\section{Significant of the study.}

The significance of this research work is aimed to reveal the impact of collection and acquisition of library materials on library services in academic library. This research work could be used to improve on the problem of collection and acquisition of materials like inadequate fund, paucity of published books, non-professional staff, library policy and foreign exchange transactions. This work will also proffer practical approach with strategies to make collection and acquisition of materials easier. Library management could find the result of this study as a useful tool for easy collection and acquisition of materials. The result of this research can as well be used to calculate the practical approach to collection and acquisition of materials.

\section{Scope and Limitations of the study.}

This study is not limited to any library with low infrastructural and poor standard. It is intended to cover the meaning, problem, method, effect to library and the services of the library vice visa, its effect on the users at any level with the aim to cater for the researchers in their research work.

\section{Literature Review.}

\section{Acquisitions and Developments,}

Acquisition and development is broad term used for formulation of a systematic general plan for the creation of a library acquisition and to meet the needs of those library clients.

Acquisition development is one of the most important activities of a library and information centre, be it small and specialized, large and academic (Giri, Sen\&Mahesh, 2015).

Using information resources produced both from inside and outside the organization. This process involves several components that include, the library's mission, assessment of patron's needs, strength and weakness of the existing collection and tools for identifying the relevant and quality materials (Kumar, 2012).

According to the International Federation of Library Associations and Institutions (IFLA) collection and acquisition development are mainly focuses on methodology for acquisition of print as well as eresources (nd). Wittenbach, Stefanie (2005), as cited by Umesha, M. B. and Sarasvathy,P (2017), opined that the restructuring of collection development at the University of California Riverside University Libraries. In this article, author has presented a new system that has created more accountability for the resource budget. The findings of result showed that users are more aware about resources purchased in their own area.

Ameen, Kanwal (2006), as cited by Umesha, M. B. and Sarasvathy,P (2017), opined in his article discussed all kinds of managerial and practical issues pertaining to collection development and its acquisitions. The paper has attempted to explore the relationship between the use of varying collectionrelated terminologies and ever-emerging forms of scholarly publishing in libraries. It was found that the related emerging terminology has been expanding rapidly because of the direct impact of the eresources developments. 


\section{Acquisitions of Library Materials.}

The encyclopedia of library and information science defines acquisition as the function of obtaining the library materials, which make up the library's collection. Acquisition is concern with the building up of the library collection. It is the means by which the library collection is kept up to date, it's also involves adding new materials to the library.

The acquisition of information resources in print format is an important function in Libraries. Even in the advent of information technology and the subsequent emergence of the digital paradigm, print materials still have a central place in library collection and publishing industry.(Carr, 2007), Acquisition is the process of securing materials for the library through purchase, gifts and donation or through exchange programmes. (Evans, 2000), as cited by Akinola, S.A. ((2019).Once materials have been selected by staff or requested by users, the acquisition process begins-that is locating the right item, ordering it and processing the item and paperwork once they arrive. Although acquisition procedures may vary depending on the library's mission and resources, all libraries have some goals in common.

\section{Factors affecting acquisition and collections in academic libraries.}

Academic libraries and collections exist to serve academic purpose for learning, teaching, and research in an academic environment for the needs of their clients. The libraries are as varied as those needs. Therefore, the libraries do have common elements in the service they provide and they focused on collections with their knowledge of staff who are able to adopt to the changing needs of their clients base. The term academic libraries defined by Wikipedia is a library that is attached to a higher education institution and serves two complementary purposes: to support the curriculum, and to support the research of the university faculty and students. Bogel (2011) opined in his survey of 4182 respondents sought to understand the idea of shared reading which was mainly about book selection based on recommendation from friends, family members, public or school librarian or other adults. The result from his study was stunning as recommendation from friends stood at $81.6 \%$ while cumulative recommendation from school or public librarians was between 3 to $6 \%$. Although, this doesn't mean other factors influencing borrowing from library collection are ineffective, it only emphasizes the importance of social interaction with peers as a motivating factor to identify not just what to read but why these books are borrowed.

\section{Library users satisfactions.}

Library user satisfaction implies how users feel after using the information resources and services and their willingness to return to the library when next they need information (Ikenwe and AdegbileroIwari, 2014).

Iwhiwhu and Okorodudu (2012), opined that users satisfaction of library information resources and services is a way in which users judge the adequacy of the library information resources and services rendered to them and also if their expectations are provided to them. According to Ijiekhuamhen, Aghojare and Lerdinand (2015) opined the level of using the library depends on users' satisfaction with the available information resources and services rendered to them.

Oyelekan and Iyortsuun (2011) conducted a study on evaluative study of reader services in University of Agriculture library, Makurdi. The study revealed that users were satisfied with lending services, 
reserve materials services and bindery services. The study also showed that inter library loan, current awareness, library orientation and photocopying services were not suitable to them.

\section{Library services in academic rems.}

According to Umoh, B. E. (2017) opined that library services have to facilitate academic success; academic libraries must provide access to a broad range of information resources. Reference and referral services, orientation activities, and instruction sessions that teach students the critical thinking skills necessary for using library information resources are one of the basic services provided by the staff particularly to new students of the institutions in Nigeria. Varied and innovative orientation programme to new users of the library include teaching by personal contact and through the preparation and use of instructional information resources in various formats. Introducing the library users to the library activities, provide a gateway to all future inquiries, not only preparing the users as independent users but also teaching them to use information sources as citizens, as consumers, as professionals, and for recreational purposes.

\section{Value of collections and development policy in library.}

A written collection development policy is intended to clarify objectives and to facilitate coordination, both within a library or a library system and among cooperating libraries. If it is well done it should serve as a day-to -day working tool that provide the necessary guidelines for carrying out the majority of tasks within the area of collection building. A collection development policy serves a board range of function, and infect it continues by presenting a dozen of reasons why a policy statement should be devised.

Government interest in the effectiveness of higher education seems to be increasing as the role of knowledge workers becomes more valuable in contributing to economic growth and national competitiveness. If policymakers in the United States emulate the Bologna process, with student learning as the primary measure of quality, it is likely that government regulation and calls for accountability will only increase (Lederman, 2010b). 


\section{3 . Data Analysis , Interpretations and Discussions}

\section{Personal Data's}

\section{Age Distributions.}

The age distribution table of the respondents shows that it ranges below 20 years (3) 6.7\% 19-24 years were (12) 26.7\%, 25-30 years were (25) 55.5\% and 31-35 years were (50) 11.1\%, Obviously, the 31-35 age ranges were the major users as at the time the research was carried out

\section{Table 1}

\begin{tabular}{lll} 
Age Ranges (Years) & No of respondent & Percentage \\
\hline Below 20 & 120 & $33.3 \%$ \\
$20-24$ & 90 & $25 \%$ \\
$25-30$ & 80 & $22.2 \%$ \\
$31-35$ & 70 & 19.4 \\
Total & 360 & $100 \%$
\end{tabular}

\section{QUESTIONS 1}

What are the material acquired in library.?

(1a) accessibility

\section{Accessibility to library material (for acquisitions ).}

\section{Accessibility of library materials.}

It was noted on the different needs of the respondents, that the study on access to information materials shows that (95) $26.4 \%$ of the respondents were accessible to materials, needed in their research at the library while (66) $18.3 \%$ not accessible while a high magnitude of the respondents prefers averagely accessible of (154) $42.8 \%$ and (45) $12.5 \%$ of the respondents were very accessible to library materials.

\section{Table 4}

\begin{tabular}{lll} 
Access to information materials & No of respondent & Percentage \\
\hline Accessible & 95 & $26.4 \%$ \\
Not accessible & 66 & $18.3 \%$ \\
Averagely accessible & 154 & $42.8 \%$ \\
Very accessible & 45 & $12.5 \%$ \\
& & \\
Total & 360 & $100 \%$
\end{tabular}




\section{QUESTIONS 1}

What are the material acquired in library.?

(1b) determinations of user

\section{Schools / courses of the respondents.}

The research result generated from the background information of the library users cut across the schools and level of the respondent's.

School of communication and information Technology (ICT) were (44) 12.2\%, School of Engineering were (45) 12.5, School of Applied Science were (80) 22.2\%, School of Environmental were (66) 18.3\%, School General Studies (30) 8.3\% and School of Business and Management Studies were (95)26.4\%.This shows that the targeted respondents have a fair representation of distribution.

\section{Table 2}

\begin{tabular}{|c|c|c|}
\hline Schools & No of respondent & Percentage \\
\hline \begin{tabular}{lr}
\multicolumn{1}{c}{ School } & of \\
communication & and \\
information Technology &
\end{tabular} & 44 & $12.2 \%$ \\
\hline School of Engineering & 45 & $12.5 \%$ \\
\hline School of Applied & 80 & $22.2 \%$ \\
\hline Science & & \\
\hline School of & 66 & $18.3 \%$ \\
\hline Environmental & & \\
\hline School General Studies & 30 & 8.3 \\
\hline $\begin{array}{l}\text { School of Business and } \\
\text { Management Studies }\end{array}$ & 95 & $26.4 \%$ \\
\hline Total & 360 & $100 \%$ \\
\hline
\end{tabular}

\section{QUESTIONS 1}

What are the material acquired in library.?

(1c) rate of usage of library

\section{Frequent user of Library.}

Considering the currency of the materials in selected institutions ,main library, it is important to note that the table shows $180(50 \%)$ often uses the library while $100(27.8 \%)$ very often uses the library and $80(22.2 \%)$ rarely use the library. 
Table 3

\begin{tabular}{lll} 
USAGE OF THE LIBRARY & No of respondent & Percentage \\
\hline Often & 180 & $50 \%$ \\
Very often & 100 & $27.8 \%$ \\
Rarely & 80 & $22.2 \%$ \\
Total & 360 & $100 \%$
\end{tabular}

\subsection{Availability of the Information materials}

It is noted that only (180) of the respondents with (50\%) were not always getting information materials needed in their research at the library while (100) of $27.8 \%$ were always getting materials for their research work. This probably shows that the library is rich in collections.

\section{What are the material acquired in library.?}

\section{(1d) Type of information material consulted in library.}

The study shows that (170) $47.2 \%$ of the respondents consulted Serials materials, (100) $27.8 \%$ consulted textbooks in the library while (90) $25 \%$ of the respondents consulted reference materials. However it was discovered that serials were mostly used main library.

\section{Table 5}

Information materials

No of respondents

Percentage

\begin{tabular}{lll}
\hline Serials & 170 & $47.2 \%$ \\
Textbooks & 100 & $27.8 \%$ \\
Reference & 90 & $25 \%$ \\
Total & 360 & $100 \%$
\end{tabular}

\section{QUESTIONS 1}

What are the material acquired in library.?

(1e) Relevant of shelve books in course of studies.

The findings shows that only (90)25\% of respondents regards the shelved books as very relevant to subject needs and this is corroborated by (140) $38.9 \%$ of the respondents also who indicated as relevant the shelve books to subject needs while (70)19.4\% agreed to it as averagely relevant and (60) $16.7 \%$ of the respondents sees the shelved books as not relevant to their needs. 
Table 6

Relevance of shelved books to No of respondents Percentage

subject needs

\begin{tabular}{lll}
\hline Very relevant & 90 & $25 \%$ \\
Relevant & 140 & $38.9 \%$ \\
Average relevant & 70 & $19.4 \%$ \\
Not relevant & 60 & $16.7 \%$ \\
Total & 360 & $100 \%$
\end{tabular}

\section{QUESTIONS 1}

\section{What are the material acquired in library.?}

\section{(1f) Users and Library (satisfactions)}

The study shows that (80)22.2\% of the respondents were very satisfied with the library materials, (190) $52.8 \%$ were satisfied and (90) $25 \%$ were not satisfied.The implication of these finding probably is that, in spite of the partial satisfaction, the respondents are expecting more library resources to cater for their interest and needs that the library resources are not well arranged, obsolete, inadequate, difficult to locate and not available.

\section{Table 7}

\begin{tabular}{lll} 
Users satisfaction & No respondents & Percentage \\
\hline Very satisfied & 80 & $22.2 \%$ \\
Partially satisfied & 190 & $52.8 \%$ \\
Not satisfied & 90 & $25 \%$ \\
Total & 360 & $100 \%$
\end{tabular}

\section{In conclusion for table Questions 1 on acquired material.}

\section{Conclusion.}

The focus of this study has been on acquisition of library materials as a correlates to main library service. This was examined from various perspectives to achieve the purpose of this particular study. In order to achieve the objectives which this study was based, the researcher uses all avenues so as to get the information needed to achieve the objectives of the study. Based on the objectives of the study, the following conclusions were drawn with regard to the research questions.

From the findings, the acquisitions development librarian and the management of any library play an important role in providing the greatest number of library resources to meet the information needs of the library clientele. library has a written policy for collection development of materials at the initial stage but now, library management apparently are not making any move to resuscitate the strict adherence to the policy. However, no written policy to be followed or implemented for analysis, selection, acquisition, weeding and evaluation , 
neither is there any ongoing plan to re-invigorate the policy now that the computer system are introduced into library system.

The findings also reveals that the vast majority of respondents in the library under study were partially satisfied with the library resources while some were not satisfied with available resources. These indicated that the respondents are expecting more library materials to cater for their research needs.

Through the questionnaire administered, the respondents supported that the shelved books are relevant to the subject needs of the researchers. This was because $38.9 \%$ of the respondents counted as relevant, only $16.7 \%$ of the respondents counted the shelved books as not relevant.

The actual funding pattern of the institution could not be determined. The study indicated that the library is not adequately funded. Most of the materials are purchased by foreign author at the initial time has been abandoned when there is no enough fund to subscribe to them again. Reasons for these are evidently traced back to short fall or economic reforms and face value treatment, sole gift, apathy of the library committee management to address the need of the library aggressively with high priority from the data analysis selection of the library materials are done by the use of their personal discretion, library is presently depended on the past glory. The study reveals that the rich collections, the observed architectural design of the library and the orderly arrangement of books were adequately organized.

\section{Recommendations.}

Based on the findings of the research, it is recommended that a standards written policy be established for the collection development processes, for the growth and the development of library. Adequate funds are to library management or parent institution to cater for acquisition of essential information resources of the library under study.

The most striking characteristics of today's information environment are the pace of technological innovation. Therefore, the library under study should as a matter of priority begin the automation of their collection processes. This can be operated hand in hand with the manual method of cataloging. The selection and acquisition of library materials be decentralized. More professionally qualified staff should be employed to handle effectively the collection development processes of the library materials.

Weeding should be done regularly to create space for new books and easy access for materials on the shelves. The library should be encouraged to cooperate with other libraries locally and internally for provision o needed information materials for the selection of the library users.

Emphasis should be placed on the orderly arrangement of the shelf to facilitate easy location of the materials on the shelf, while users education programme must be promoted in the library. 


\section{References}

Akinola, S.A(2019).An assessement of acquisition andcollectiondevelopmentactivities in academic libraries: astudy of joseph ayo babalolauniversity ikeji - arakeji, Philosophy and Practice (e-journal)Libraries at University of

Nigeria. Library LincolnDigitalCommons@University of Nebraska - Lincoln

Arizona Department of library, and public records, (2011). Collection Assessment. Retrievedfrom:http://www.geocities.com/Athens/Styx/7534/UNIVERSITY/TLshi p/Coll Eval.html?20094 on11th June 2019

Bogel, G. (2011). Choosing the right book: Factors that affect children's reading. library and information Practice(6(1)), pp. 74-77.

Evidence based

Carr R (2007). The academic research library in a decade of change. Oxford: Chandos

Publishing.

Giri,Rabishankar, Sen, B.K \& Mahesh,G.(2015). Collection development in Indian

academic libraries: An empirical approach to determine the number of copies for acquisition. DESIDOC Journal of Library \& Information Technology, 35(3),184-

92.RetrievedNov16,2016from:https://www.researchgate.net/publication/276026189_Collection_Developm ent_in_Indian_Academic_Libraries_An_Empirical_Apprach_to_Determine_the_Number_of_Copies_for_

Acquisition3.

Ijiekhuamhen, O. P., Aghojare, B. \& Ferdinand O. A. (2015). Assess users' satisfaction on academic library performance: a study. International Journal of Academic Research and Refliction. 3(5), 66-77.

Ikenwa, I. J. \& Adegbilero- Iwari, I. (2014). Utilization and user satisfaction of public library services in south- west, Nigeria in the 21st century: a survey. International Journal of Library Science, 3(1), 1-6.

Iwhiwhu, B. E \& Okorodudu, P.O. (2012). Public library information resources, facilities and services: User satisfaction with Edo State Central library, Benin City, Nigeria. Library Philosophy and Practice.

Jena, Sudhir. Kumar.(2012). Collection Development for Academic Libraries in the digital age. Asian

Academic Research Journal of Social Science \& Humanities, 1(2), $\quad$ 88-96. Retrieved Nov14,2016 fromhttp://www.asianacademicresearch.org/august2012/paper081.pdf4.Kumar, P. K. Suresh. (2012).

University Libraries in Kerla: A SWOT analysis for marketing. Library Phylosophy \& Practice,1-12. Retrieved Nov 15,2016 from:http://digitalcommons.unl.edu/cgi/viewcontent.cgi?article=1900\&context=li bphilprac5.

Kumar, P. K. Suresh. (2012). University Libraries in Kerla: A SWOT analysis for marketing. Library $\begin{array}{llllll}\text { Phylosophy } & \& & \text { Practice,1-12. } & \text { Retrieved } & \text { Nov } & 15,2016\end{array}$ from:http://digitalcommons.unl.edu/cgi/viewcontent.cgi?article=1900\&context=li bphilprac5.

Lederman, Doug. "No Letup From Washington.” Inside Higher Ed. 2010. http://www.insidehighered.com/news/2010/04/13/hlc.

Lederman, Doug. "Slipping (Further) Off the Pedestal.” Inside Higher Ed. 2010. http://www.insidehighered.com/news/2010/02/17/squeeze 
Osburn, C.B. (1990) Impact of collection management practices on intellectual freedom, Library Trends, 39(12):168-182.

Oyelekan, G. O, \& Iyortsuun, J. A. (2011). An evaluative study of reader services in University of Agriculture library Makurdi. An international Journal of Information and Communication Technology (ICT), 8(2), 129-137

Rajinder, K. and Rupesh, G. (2017) Collection development in academic libraries with special reference to digital era. International Journal of Digital Library Services. IJODLS | Geetanjali Research Publication 107 . Vol. 7, April - June, 2017, Issue - 2 www.ijodls.in ISSN:22501142 (Online), ISSN 2349-302X (Print)

Wittenbach, Stefanie(2005). Restructuring collection development for empowerment Collection building, 2005, 24(3), p.83-86.

and accountability. 